DOI: $10.14451 / 2.158 .14$

\title{
КЛАССИЧЕСКИЙ ТИП ПРАВОПОНИМАНИЯ. ЕСТЕСТВЕННОЕ ПРАВО В РУССКОЙ ПРАВОВОЙ МЫСЛИ ХІХ-ХХ ВЕКА.
}

\author{
(c) 2021 Сухобок Татьяна Владимировна
}

аспирант кафедры «Теории и истории права и государства; Истории учений о праве и государстве» Балтийский федеральный университет имени Иммануила Канта, Россия, Калининград E-mail: Sukhobok94@mail.ru

В статье рассматривается процесс становления и развития отечественной правовой мысли в области естественного права XIX-XX века. Дается определение категории «правопонимание», рассматривается представление отечественных философов о категории “право», с позиции развития его в концепции естественного права. Исследуется понимание данной категории отечественными философами права конца XIX - начала XX веков. Рассмотрена отечественная правовая мысль представителей классического естественного права, школы возрожденного естественного права и неокантианцев. Проанализировано и показано влияние государства и правящей элиты на процесс развития отечественной юриспруденции и русской правовой мысли. Рассмотрены проблемные моменты, которые повлияли на развитие естественного права России XIX-XX века.

Ключевые слова: Право, правопонимание, естественное право, возрожденное естественное право, государство, политика государства, теории.

Правовая теория в качестве основы своего построения использует определенное понимание права, которое выступает как дальнейшая основа познания всех правовых феноменов. Именно поэтому, понятие права содержит в себе определенную правовую концепцию. Но, важнее то, что образ права, складывающийся в рамках определенного типа правопонимания оказывает влияние на реализацию права на законодательном уровне.

Прежде чем начать изучение классического типа правопонимания, необходимо определить какое место занимает категория "правопонимание" в системе юридического научного знания. Тип правопонимания представляет собой теоретико-методологический подход к формированию определения права. Многообразие представлений о праве обусловлено социокультурными и индивидуальными характеристиками [1. С. 40].

Так, в каждом временном периоде, в зависимости от направленности научного знания и политики государства формируется свое направление относительно правопонимания.

B конце XIX - начале XX века концепция естественного права была актуальна, и относилась к числу классических правовых доктрин. Отечественные правоведы и философы изучающие и развивающие данную концепцию придерживались взглядов, что наряду с подвижным и изменчивым положительным правом существует вечное естественное право, коренящееся в природе человеческого разума и отношениях [2. C. 257-258].

Концепция естественного права развивалась до начала XX века, но в процессе своего развития естественное право неоднократно изменялось. Идеи, принципы и основные положения теории естественного права впервые были отражены в теоретических работах XVIII - первой половины XIX века таких российских мыслителей как: В.Н. Татищева, С.Е.Десницкого, А.П.Куницина, А.Н.Радищева, Н.М. Муравьева и других. [3. С. 13-76].

Именно на этот период приходится новый этап развития в отечественной юриспруденции концепции естественного права. При этом, в вопросах интерпретации и систематизации позитивного права российская юриспруденция 1860-1870x годов являлась догматической [4].

При анализе работ российских ученых необходимо учитывать, что на становление и понимание ими теории естественного права огромное влияние оказали работы европейских ученых XVII-XVIII веков: Гуго Гроция, Кристиана Томазиуса, Кристиана Вольфа, Роберта Потье и других сторонников теории естественного права.

Однако, не смотря на активное развитие правовой мысли российских юристов и философов 
права в области естественного права, политика государства не давала идеям естественного права интенсивно развиваться на законодательном уровне. Так, правительством в 1835 году было утверждено положение о запрете преподавания естественного права [5]. Основная проблема выражалась в том, что на фоне активного развития отечественными учёными идей естественного права, государство будучи приверженцем позитивного права, ограничивало законодательно его развитие. Только в XIX веке в отечественных институтах учёным было разрешено преподавать идеи естественного права.

Новым этапом развития отечественного естественного права, можно считать период проведения Александром II судебной реформы, которая ввела принципы равенства сторон, суд присяжных и институт профессионального адвоката [6. С. 287].

В Российской империи была создана судебная система, которая на тот период была самой передовой в мире, резко возрос престиж юридической профессии, спрос на квалифицированных юристов. А концепция естественного права получила новое прочтение и распространение в государственно-правовой мысли России того времени.

Интенсивное развитие отечественной правовой мысли дало положительные результаты, и уже к середине XIX века идеи отечественных юристов в области естественного права стали неотъемлемой частью кодифицированного законодательства, а идеи естественного права стали частью российской догматической юриспруденции.

В период XIX-XX века отечественная правовая мысль была интересна тем, что учёные - приверженцы позитивизма подчеркивая деление права на естественное и позитивное, не противопоставляли их и не проводили между ними непреодолимых границ. В этот период многие юристы и философы права, такие как: Б. Н. Чичерин, Н.И. Палиенко, Г. Ф.Шершеневич и многие другие, признавая позитивное право, отводили праву естественному роль идейной оценки существующего законодательства [7. С. 93-98].

Своеобразие русской концепции естественного права заключалось в том, что на нее огромное влияние оказывала немецкая философия. Теория И.Канта качественно изменила представления о естественном праве, заменив категорию «всеобщей воли народа» на «априорную всеобщую волю». Так же, Р.Штаммлер положил начало пониманию естественного права с изменяющимся содержанием, что получило дальнейшее развитие в российской философии права. Российские неокантианцы на рубеже XIXXX веков продолжили разработку естественноправового учения [8. С. 304].

Большое значение в этом направлении имеют работы П.И.Новгородцева, являющегося видным российским учёным. П.И. Новгородцев истолковал идеи естественного права в рамках вечного неотъемлемого права человеческой личности. П.И.Новгородцев считал, что естественное право - совокупность нравственных представлений о праве. П.И.Новгородцев констатировал «несводимость права и нравственности друг к другу» [9. С. 30].

Можно говорить о том, что в конце XIX - начале XX века естественное право в отечественной правовой мысли стало восприниматься как регулятор общественных отношений. Основной задачей естественного права становится поиск абсолютного начала, исходя из которого возможно было решать любые задачи позитивного права.

Следует сказать о начале возрождения естественного права в Российской Империи, после провозглашения необходимости этого возрождения в конце XIX века в работах П.И.Новгородцева и Л.И.Петражицкого, а позднее Н.И. Кареева, Е.Н. Трубецкого, Б.А.Кистяковского, В. М. Гессена и многих других.

Представители школы «возрожденного естественного права» выдвигали противоположную программу. А Е.Н.Трубецкой, анализируя проблемы соотношения права и нравственности, признавал тесную взаимосвязь, всеобщность и вечность начал права и нравственности [10, С. 222].

П.И.Новгородцев создал концепцию правового государства, в котором акцент делался не на правовых обязанностях, а на политических и гражданских правах личности, что противостояло укоренившемуся в русском сознании этатизму. Б.А. Кистяковский, так же как П.И.Новгородцев, стремился соединить «нравственный априоризм» с идеей общественного развития, что нашло отражение в разработанной им интегральной теории права [11. С. 147].

Идеи школы возрожденного естественного права строились на том, что «в отличие от клас- 
сического естественного права, в котором нормы имели незыблемый характер, новое не содержит системы неизменных норм, но познает безусловное начало, позволяющее достичь тех рубежей, которые задаются праву обстоятельствами конкретного времени и пространства»о чем писал в своих научных трудах П.И.Новгородцев [12. С. 269].

Таким образом, необходимым условием существования любого общества является регулирование отношений его членов. Нормативное регулирование носит общий характер, его правила направлены на всех членов общества или определенной его группы. Индивидуаль- ное регулирование направлено на конкретный субъект. Оба вида регулирования связаны между собой. На развитие российского права и правовой мысли, в большей мере, оказало влияние непринятие государством и правящей элитой идеи естественного права в тот момент, когда естественное право находилось в стадии расцвета на Западе, и активно развивалось в отечественной правовой мысли. Это привело к тому, что к моменту принятия естественного права государством и правящей элитой, идеи естественного права потеряли свою актуальность на Западе. И в дальнейшем не получили своего развития в отечественной правовой мысли.

\section{Библиографический список}

1. Финогентова О.Е., Долголенко Т.Н.Интегративные концепции как основа современного отечественного правопонимания / Финогентова О.Е., Долголенко Т.Н. // Вестник СЮИ, 2011.

2. Любашиц В.Я., Смоленский М.Б., Шепелев В.И. Теория государства и права. / Любашиц В.Я., Смоленский М. Б., Шепелев В.И.- Ростов-на-Дону: Феникс, 2003.

3. Куприц Н.Я.Из истории государственно-правовой мысли дореволюционной России. / Куприц Н.Я.- М.: МГУ, 1980.

4. Борисова Т. Ю. Сборник законов Российской Империи: феномен самодержавной законности / Т.Ю Борисова // Право и история. 2012. Обзор № 30 (03).

5. Высочайше утвержденный Общий устав Императорских Российских Университетов от 26 июля 1835 г. электронный ресурс: https://base.garant.ru/58090287.

6. Томсинов В.А. Юридическое образование и юриспруденция в Россиив эпоху «великих реформ» (60-е - начало 80-х гг. ХІХ в.): Учебное пособие / В.А. Томсинов; Московский гос. ун-т им. М. В. Ломоносова, Юридический фак., Каф. истории государства и права.- Москва: Зерцало - M, 2013.

7. орнев А.В. К вопросу о правопонимании в дореволюционной России // Государство и право. 1998 . № 5.

8. Фролова Е. А. Методология и философия права: от Декарта до русских неокантианцев: монография / Фролова Е.А.- Москва: Проспект, 2017.

9. Новгородцев П.И. К вопросу о современных философских исканиях: ответ Л.И.Петражицкому / Новгородцев П.И.- Москва, 1911.

10. Трубецкой Е. Н. Энциклопедия права / Оформление обложки С. Шапиро, А. Олексеенко / СПб.: Издательство «Лунь», 1998.

11. Финогентова О.Е. Соотношение позитивистского и естественно-правового начал в политико-правовой мысли россии на рубеже XIX-XX вв./ Финогентова О.Е.// Правовое государство: теория и практика. 2014. № 3(37)

12. Новгородцев П. И. Введение в философию права: Кризис современного правосознания / Новгородцев П.И.М.: Наука, 1997. 